\title{
Stability Analysis And Landslide Countermeasures Using Plaxis2d In The Cigentis Watersheds, Karawang, West Jawa
}

\author{
A'isyah Salimah ${ }^{1}$, Muhammad Fathur Rouf $\operatorname{Hasan}^{1}$ \\ \{aisyah.salimah@pnj.ac.id, rouf@sipil.pnj.ac.id\} \\ Civil Engineering Department, Politenik Negeri Jakarta, Jln. Prof. Dr. G. A. Siwabessy, UI Depok
}

\begin{abstract}
Watershed is a vulnerable environment for soil erosion to occur. High intensity rainfall causes high river water overflowed and eroded rocks as well as soil in river banks referring to landslide. Cigentis is upstream area of Citarum watershed which is functioned to arrest the water flow at the upstream in Mekar Buana, Karawang. This study aims to analyze landslide countermeasures by applying slope reinforcement and drainage refinement to prevent recurrence of slides. The methods used are survey investigation, laboratory test, stability analysis for slope reinforcement utilizing PLAXIS2D and drainage refinement. The river banks are strengthened by applying gabion mesh retaining wall. The gabion mesh dimensions are $2.5 \mathrm{~m}$ in length; $1 \mathrm{~m}$ in width as long as $33 \mathrm{~m}$. The result indicates the safety factors for existing condition 1.23 while the safety factor for strengthening condition 1.79. It can be concluded that the condition of river banks with reinforcements is in safe conditions.
\end{abstract}

Keywords: Watersheds, erosion, landslide, PLAXIS2D, gabion mesh, cigentis.

\section{Introduction}

The soil surface condition is not constantly in the form of flat area, yet it contains different topography in each area. The difference of elevation causes ground movements specifically landslide. Slide is defined as a mass movement of rocks or debris in many types such as sliding or shearing and rolling due to gravity which follow the steepness of slope [1], [2].

Rainfall could induce ground movement, the water that infiltrates to the soil and accumulates along the dipping slope would reduce the effective stress and decrease the soil shear strength. Excessive rainfall would highly trigger landslide in the seepage area of slopes. [3] revealed that landslide disaster in Indonesia is influenced by climate condition with high intensity rainfall [4]. According to compiled data from Indonesia Disaster Data Information (DIBI) of the National Disaster Management Agency (BNPB) on January 2014, Karawang regency experienced three floods in a week which are on January $13^{\text {th }}, 17^{\text {th }}$, and $19^{\text {th }}$. This floods induced landslides in several are, one of those is in Cigentis waterfall [5].

Cigentis is the upstream area of Citarum watershed which is used to hold the water at the upstream as well as the estuary for water stream. Mekar Buana village, Tegal Waru district, Karawang regency, West Java is a river flow area of Cigentis waterfall. The tilt of slope around the village is about $15^{\circ}-20^{\circ}$, regarding this steep angle, landslide and floods are 
frequent potential disasters. Landslide level in the upstream of Citarum watershed is very poor with average value of 491 ton/day/year [6].

Landslide disaster occurred in Cigentis waterfall is located at $107^{\circ} 14^{\prime} 01.29^{\prime \prime} \mathrm{E}$ and $6^{\circ} 32^{\prime}$ 25.76" S. Considering the geological map of Cianjur quadrangle (Figure 1) the position of Cigentis waterfall is in between two highlands which lithogical unit is dominated by alluvial material such as sand and clay. This type of rock is easily dissolved in the water particularly in respectable amount and sustainable flow.

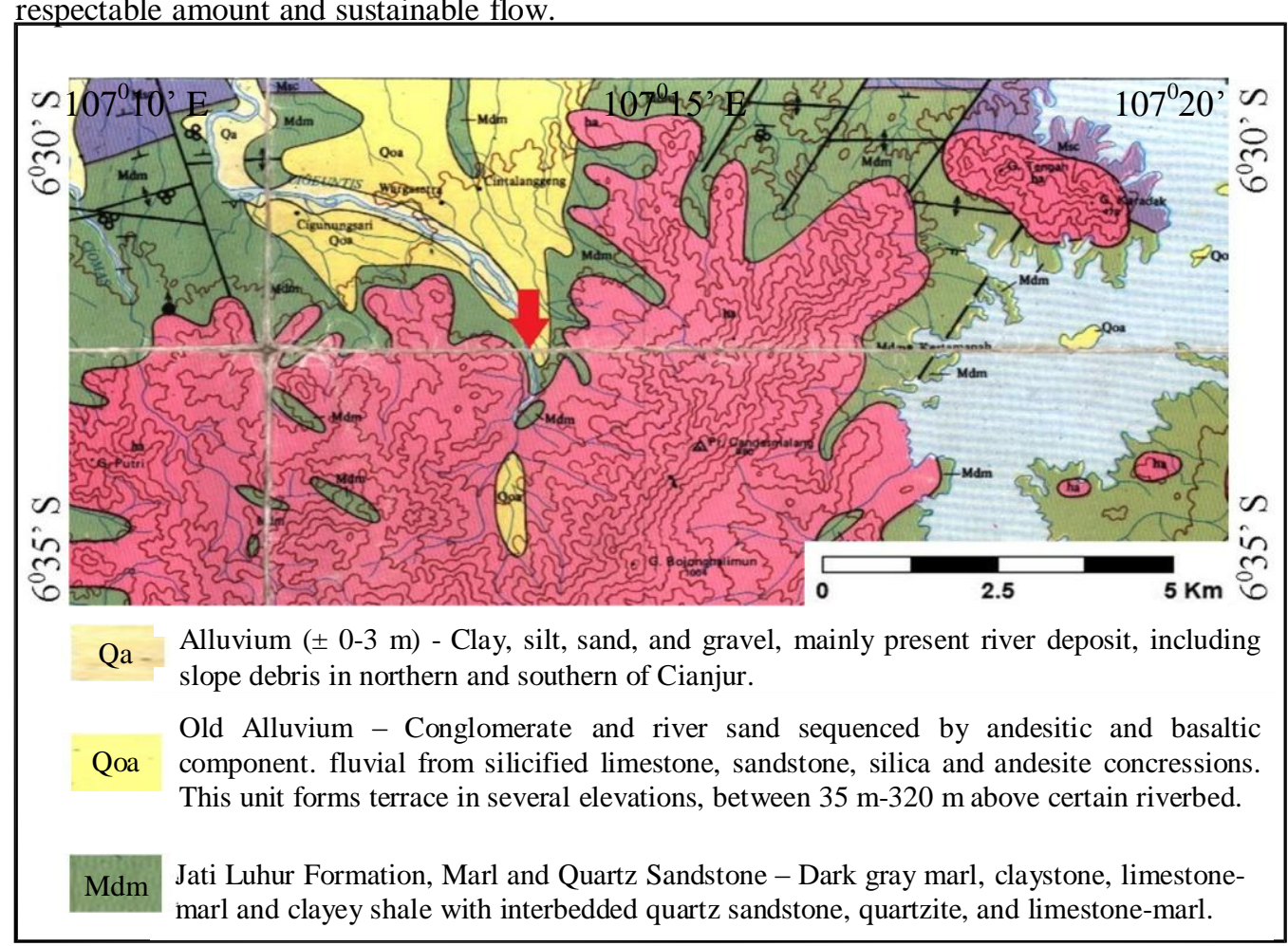

Figure 1. Regional Geological Map of Cianjur Quadrangle [7].

Landslide disaster and erosion prevention could be carried on in several methods, such as survey investigation which aims to analyze condition of landslide impact on site, analyzing soil content in research site by laboratory test, and stability analysis for slope reinforcement using PLAXIS software to acknowledge slope safety factor [8].

The finite element method has been applied by $[9,10,11,12]$ to analyze slope stability for future countermeasure. This method could be established using a program in Plaxis2D splecialized for geothecnics that could model soil beheviour. PLAXIS2D is a finite element program for geotechnical applications in which soil models are used to simulate the soil behaviour. PLAXIS2D engages specifically for analyzing deformation and stability for various geotechnical applications [13]. PLAXIS2D usage intends to do slope stability analysis which could generate a model respected to real condition on site thus the application could simplify the analysis and the countermeasure model. 
This study aims to analyze regarding slope failure countermeasures by applying slope reinforcement and drainage refinement. The analysis is done by using PLAXIS2D to create building strengthening model so that the safety factor value would be in secure condition.

\section{Methods}

This research is performed in Mekarbuana village, Tegalwaru district, Karawangregency, West Java where this area has experienced slope failure in Cigentis waterfall. The methods used in the study include survey investigation, laboratory test, stability analysis for slope reinforcement utilizing PLAXIS 2D and drainage refinement suggestion. To carry out appropriate countermeasures, certain investigation stages are necessarily executed according to suitable procedures. The following stages are investigation and countermeasures used in this study.

2.1. Investigation of river bank condition

Investigation is a process of field survey which objects to explore river bank condition. The investigation process is required to decide which obligatory test should be performed and to formulate hypothesis of landslide cause. This process also presents a view about soil reinforcement that will be offered further as an effort to prevent future landslides. In this stage, contour measurement is executed in the river slope. Figure 2 describes the slope failure site condition from field survey.

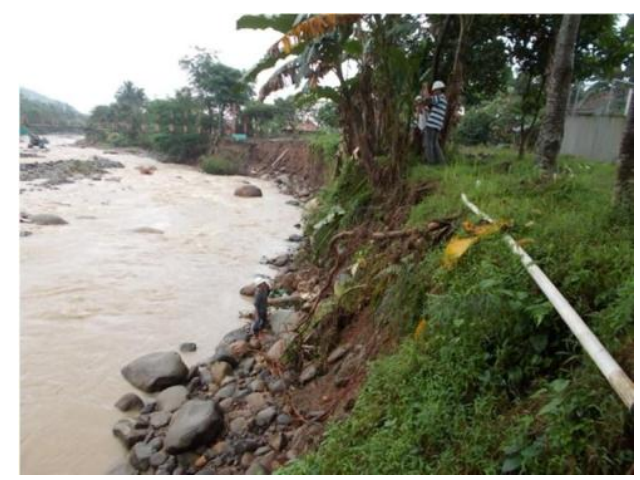

Figure 2. Slope failure site

\subsection{Investigation of soil test}

The soil test process is done by performing cone penetration test (CPT) and collecting soil sample by hand boring method. This test could show the ultimate bearing capacity, whereas soil sample from hand boring is applied in the laboratory test to understand the water content, bulk density, density, particle analysis, consistency limit, and soil shear strength test. The test of soil sample refers to American Standard Testing and Material (ASTM) [14, 15, 16, 17].

\subsection{Model Material Property}

The Mohr-Coulomb model has been used to describe the material properties. Material shear strenght to cohesion, friction angle, and normal stress are associated by the criteria of MohrCoulomb model [18]. The behavior of rocks and soil under loads is generally non-linier. The soil material parameters and retaining walls used in this slope stability analysis are explained in Table 1. 
Table 1. Material design parameters

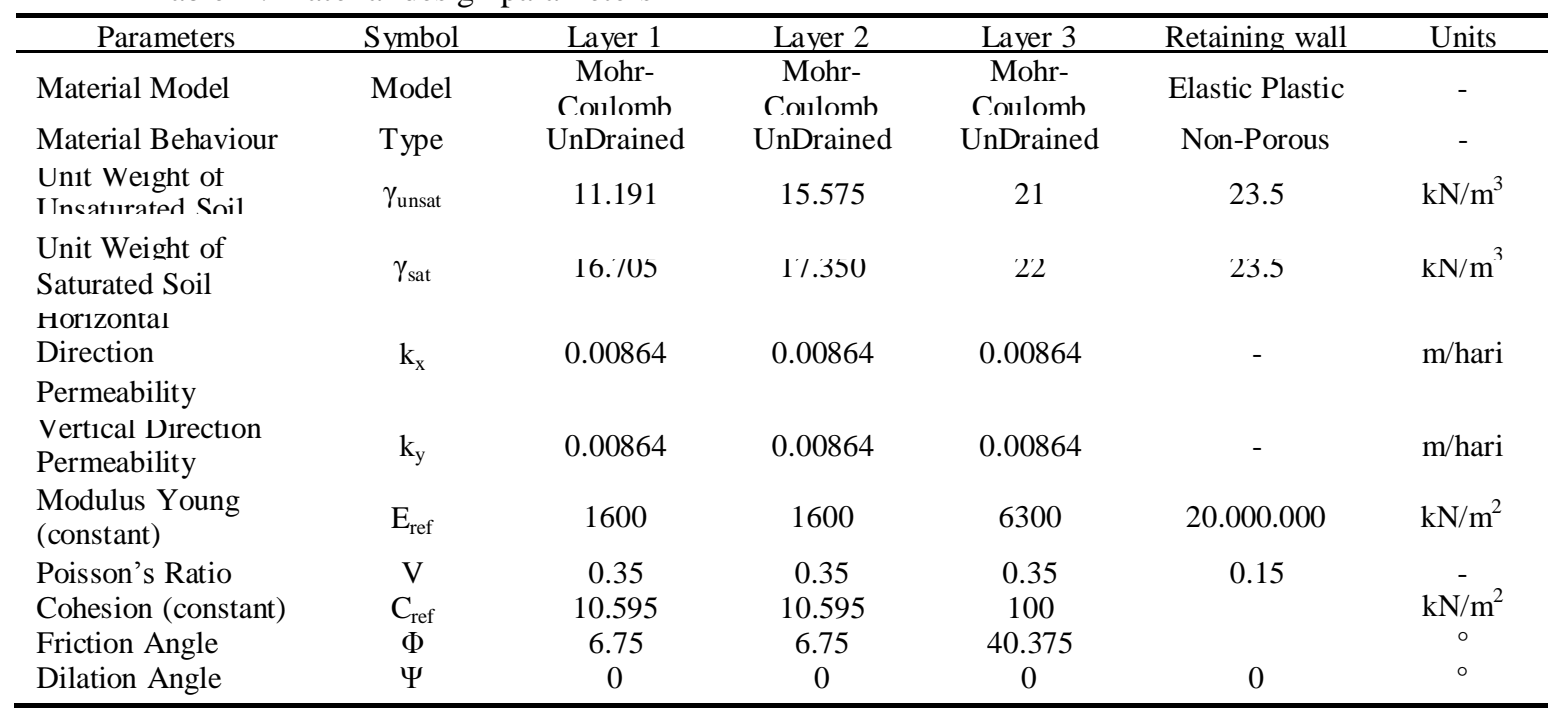

Slope stability analysis using PLAXIS2D. The geometrical model generation is graphically created by the input of soil layering, structural elements, construction stages, loading, and limit conditions in computer processing, therefore this application enables to create detailed geometrical model in the form of cross-sections. Geometrical model and 2D finite elements could be established conveniently in PLAXIS software. This software will automatically form random 2D finite element to smooth the finite element both globally and locally [13].

Soil and rocks behaviour are modelled implementing Mohr-Couloumb equation. MohrCoulomb (1910) stated that failures occurs in materials as the consequence of critical intercept of normal and shear stress [12]. This equation is employed to calculate safety factor using 'phi-c reduction' approach. Shear failure which is caused by shear strength happens in a plane that has reached limit condition as formulated by the following Mohr-Couloumb equation.

$$
=+(-) \tan \varnothing
$$

Where is a stress, uw is the pore-water pressure, and and $\varnothing$ are the intercept on the shearstress axis and the slope of the Mohr-Coulomb failure envelope [19]. Safety factor of slope is obtained by figuring the weak plane in soil layers. SF is acquired by gradually subtracting cohesion value and friction angle in soil until the soil layers experience failure [10].

\section{Result and discussion}

The visual observation result of high intensity rainfall occurs particularly on December 2013 January 2014 in Cigentis stream. The heavy rain induces the river water leaked and eroded rocks and soil in river bank, so that this endangers the surrounding building in which tower building previously located $10 \mathrm{~m}$ from river bank has become $5 \mathrm{~m}$. In addition to this perimeter, factory activity and illegal mining are worsening the damage of water catchment area that turns out to be a potentially landslide area in rainy season.the hand boring shows soil layering condition at $1 \mathrm{~m}$ depth as sandy clay with $\mathrm{q}_{\mathrm{c}} 10 \mathrm{~kg} / \mathrm{cm}^{2}$, and $3 \mathrm{~m}$ depth indicates gravelly sand. The following explanation is the result of reinforcement using PLAXIS2D. 


\subsection{Contour Design}

General description of model design of slope stability is illustrated in Figure 3 and 4. Figure 3 shows initial contour condition after slide. Figure 4 depicts contour condition after improvement using retaining wall and gabion mesh. The calculation process in PLAXIS2D could be progressed if contour design of both existing and after reinforcement are produced. The calculation process requires several soil parameters as mentioned in Table 1.

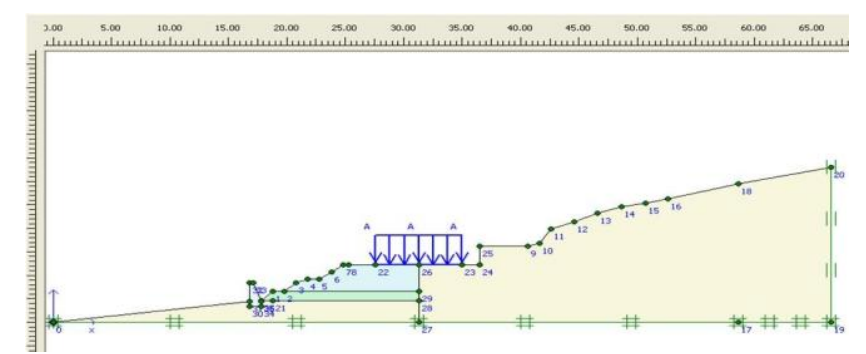

Figure 3. The initial contour condition after slide

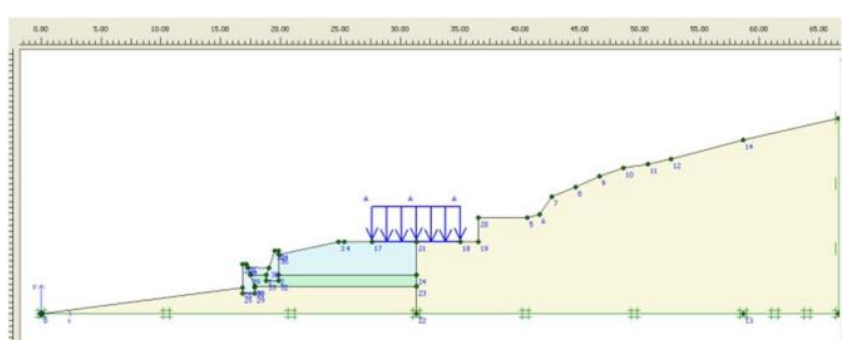

Figure 4. Reinforced contour design

3.2. Slope stability analysis result

The slope takes on dead loads from tower and its foundation modelled as equal load showed by blue arrow in downward direction in Figure 5 and 6. The input material data for tower and foundation load is $44,42 \mathrm{kN} / \mathrm{m}^{2}$. Figure 5 (a) and (b) describe the largest ground movement around tower building area. This big ground movement occurs since soil in tower perimeter is an accumulated soil which is not completely condensed. The soil test calculates average qc of $17 \mathrm{~kg} / \mathrm{cm}^{2}$, that leads to ground displacement in the area.

In this case a slope at river bank with the height of $4 \mathrm{~m}$ and slope angle of 40 degrees is considered. Figure 5 and 6 illustrate the results of numerical analysis by applying parameters shown in Table 1.

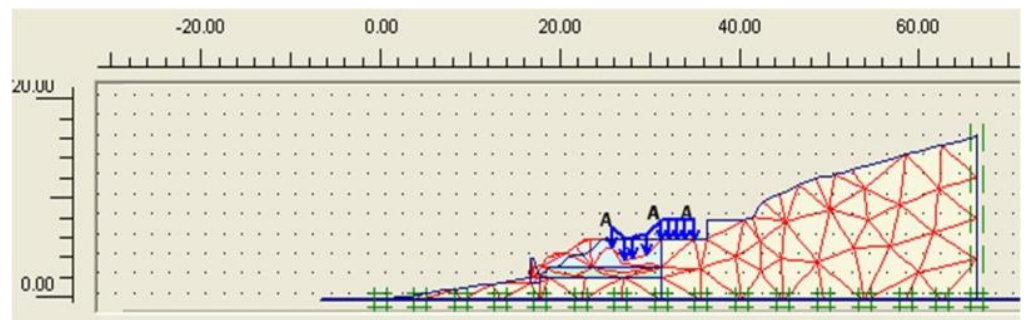

(a) 


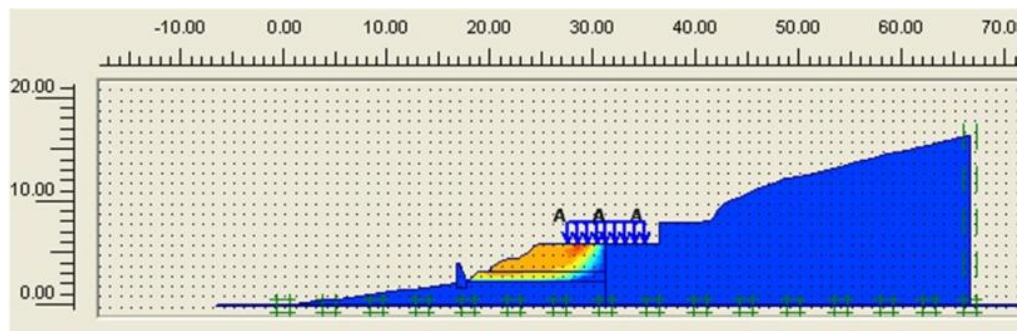

(b)

Figure 5. (a) Deformed mesh after landslide, (b) The failure plane before improvement

The deformed mesh is portrayed in the Figure 5 (a). The potential slipping zone is described in Figure 5(b) which displacement scaling and total regional displacement are depicted as well. Analysis using The Finite Element Method (FEM) could simulate failure plane reaching toe of slope in under present condition. Safety factor in this case is 1.231 (Figure 7a) which indicates that slope is very much likely to fail. The dimension of retaining wall reinforcement is width $1 \mathrm{~m}$ and height $2.5 \mathrm{~m}$. This input generates analysis as can be seen in Figure 6 which shows the failure plane after reinforcement.

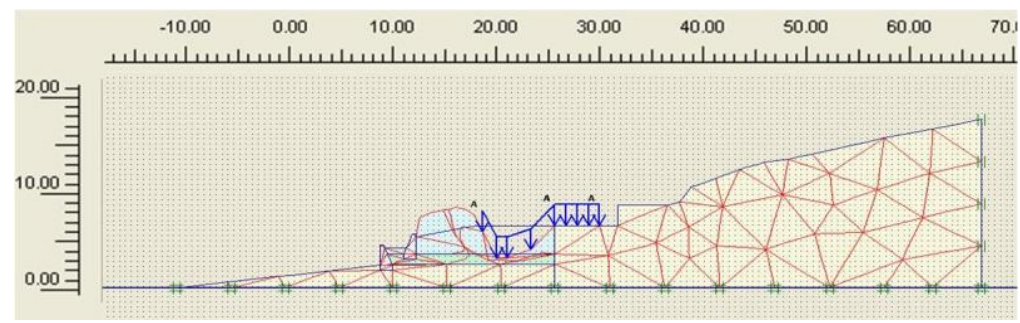

(a)

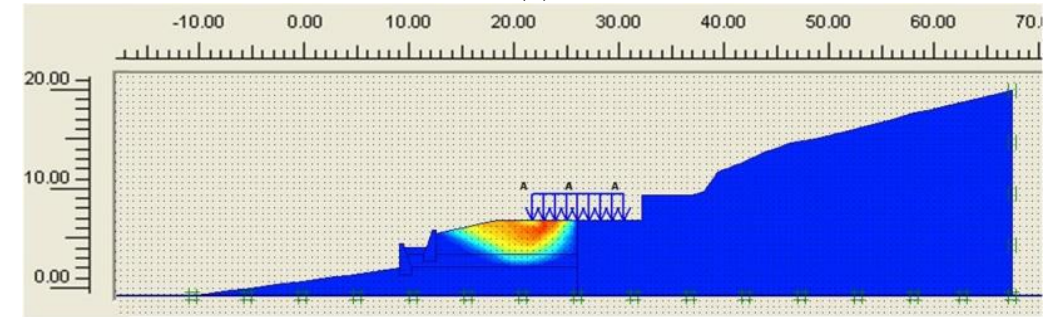

(b)

Figure 6. (a) Deformed mesh after strengthened, (b) The failure plane after repairment utilizing retaining wall

Figure 6 (a) indicates deformed mesh after strengthened using retaining wall. The potential slipping zone is described in Figure 6 (b). This measure could increase the value of SF which in this case is 1.558 (Figure $7 \mathrm{~b}$ ) greater that the minimum safety value. This result could conclude that the slope reinforcement is in secure condition. 

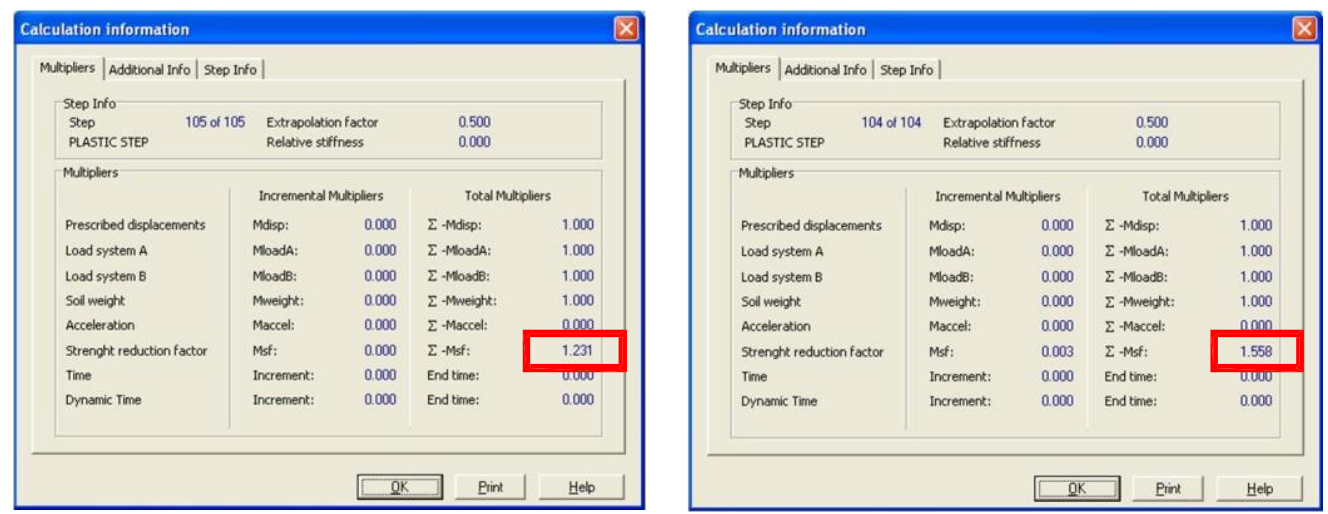

Gambar 7. (a) Safety factor for existing condition, (b) Safety factor after strengthening condition

The second stage is drainage canal plan which is divided into two parts, canal debit plan and canal dimension plan. This plan is required to accommodate rain water flow from hill, therefore this could prevent the overflow seepage of rain water that degrades soil surface in river bank.

\section{Conclusion}

Slide countermeasures in Cigentis river area could be performed by constructing reinforcement using gabion mesh and retaining wall, as well as drainage refinement. The improved countermeasure could increase the value of safety factor from 1.231 to 1.558 greater than the minimum safety value. Therefore, the slope condition is secured by applying reinforcement.

\section{Acknowledgement}

This research is carried out by remarkable assistance from local community around Cigentis river for the help during the study and Civil Engineering department of Politeknik Negeri Jakarta for loyal support so that this paper could be finished.

\section{Referrences}

[1] Thornbury, William D., 1969. Principles of Geomorphology. Amerika serikat. Departement of geology Indiana University.

[2] Selby, M. J., 1985, Earth Changing Surface, Clarendon Press. Oxford.

[3] Bachri, S. \& Sheresta, R.P. 2010. Landslide hazard Assessment Using Analytic Hierarchy Processing(AHP) and Geographic Information System in Kaligesing Mountain Area of Central Java Province Indonesia. Journal of 5th Annual International Workshop \& Expo on Sumatra Tsunami Disaster \& Recovery, 107-112.

[4] Groen, E.T. dan Jacobs, C., 2012. Risk Mapping Indonesia Sector Disaster Risk Reduction \& Emergency Aid. Cordaid.

[5] http://bnpb.cloud/dibi/xdibi_list accessed on July 2019 at 17:00 WIB.

[6] http://bpdasctw.info/ accessed on July 2019 at 17:30 WIB

[7] Sujatmiko, 1972. Geological Map of The Cianjur Quadrangle, Java. Geological Research and Development Center, Bandung. 
[8] Setyanto, Zakaria, Ahmad., Permana, Giwa Wibawa., 2016, Analisis Stabilitas Lereng dan Penanganan Longsoran Menggunakan Metode Elemen Hingga Plaxis V.8.2 (Studi Kasus : Ruas Jalan Liwa - Simpang Gunung Kemala STA.263+650) Jurnal Rekayasa, Vol. 20, No. 2, Agustus 2016,

[9] Matsui, T., and San, K. C., 1992, "Finite Element Slope Stability Analysis by Shear Strength Reduction Technique," Soils and Foundations, 32 (1); 59-70.

[10] Duncan, J. M., 1996, "State of the Art: Limit Equilibrium and Finite Element Analysis of Slopes," Journal of Geotechnical Engineering, ASCE, 122 (7); 577-596.

[11] Griffiths, D. V., and Lane, P. A., 1999, Slope Stability Analysis by Finite Elements. Geotechnique, 49(3);387-403.

[12] Kainthola, A., Verma, D., Gupte, S.S. and Singh, T.N., 2011. A Coal mine dump stability analysis - a case study. Journal of Geomaterial. 1, 1-13.

[13] Brinkgreve, R.B.J., 2007, PLAXIS 2D Versi 8, Delft University of Technology \& PLAXIS b.v., Belanda.

[14] American Standard Testing and Material (ASTM), 2000, D 2487-00: StandardPractice for Classification of Soils for Engineering Purposes (UnifiedSoil Classification System), Buku Panduan, hal 13.

[15] American Standard Testing and Material (ASTM), 2000, D 4318-00: Standard Test Methods for Liquid Limit, Plastic Limit, and Plasticity Index of Soils, Buku Panduan, hal 14.

[16] American Standard Testing and Material (ASTM), 2002, D 5731-02: Standard Test Method for Determination of the Point Load Strength Index of Rock, Buku Panduan, hal 9.

[17] American Standard Testing and Material (ASTM), 2007, C127-07: Standard Test Method for Density, Relative Density (Specific Gravity), and Absorption of Fine Aggregate, Buku Panduan, hal 7

[18] Verma, Dhananjai., Kainthola, Ashutosh., Gupte, S.S., Singh, T.N., 2013. A Finite Element Approach of Stability Analysis of Internal Dump Slope in Wardha Valley Coal Field, India, Maharashtra. American Journal of Mining and Metallurgy, 2013, Vol. 1, No. 1, 1-6. DOI:10.12691/ajmm-1-1-1 diakses pada 8 August 2019 23:18 WIB.

[19] Mohr, 1910. Kriteria Keruntuhan Batuan Mohr-Coulomb, http://eprints.undip.ac.id/33820/5/1617_chapter_II.pdf (accessed on July 2019). 